Invoking the past in graphic biographies: The life, death and ghostly return of Alexandre Boveda

Miranda-Barreiro, David

\title{
Studies in Comics
}

DOI:

10.1386/stic.10.1.27_1

Published: 01/07/2019

Peer reviewed version

Cyswllt i'r cyhoeddiad / Link to publication

Dyfyniad o'r fersiwn a gyhoeddwyd / Citation for published version (APA):

Miranda-Barreiro, D. (2019). Invoking the past in graphic biographies: The life, death and ghostly return of Alexandre Boveda. Studies in Comics, 10(1), 27-48.

https://doi.org/10.1386/stic.10.1.27_1

\footnotetext{
Hawliau Cyffredinol / General rights

Copyright and moral rights for the publications made accessible in the public portal are retained by the authors and/or other copyright owners and it is a condition of accessing publications that users recognise and abide by the legal requirements associated with these rights.

- Users may download and print one copy of any publication from the public portal for the purpose of private study or research.

- You may not further distribute the material or use it for any profit-making activity or commercial gain

- You may freely distribute the URL identifying the publication in the public portal?
}

Take down policy

If you believe that this document breaches copyright please contact us providing details, and we will remove access to the work immediately and investigate your claim. 


\section{Invoking the Past in Graphic Biographies: The Life, Death and Ghostly Return of}

Alexandre Bóveda

Autobiography and biography have played a significant role in what Jan Baetens has recently called the 'rise of the non-fictional graphic novel' (2017: 131). However, the term 'graphic novel' falls short to encapsulate the specific characteristics of comics genres that are closer to history and memory than to narrative fiction. As Martha Kuhlman argues in the same volume, "whether we consider autobiography or biography, the term "graphic novel" does not seem apposite $[\ldots]$ to call these examples "novels" misses the urgency and authenticity of their stories' (2017: 125). Although it seems that they have not been widely adopted by readers and publishers, scholars have in fact started to use alternative terms such as 'autobiographix, graphic memoir, and autography’ (Chaney 2011: 5) or ‘biographiction' (Lanzendörfer 2014). Furthermore, comics scholarship on non-fictional comics has grown since the arrival of the 'graphic novel', especially on historical comics, journalistic comics and autobiography (given the prominence of authors such as Spiegelman, Satrapi, Bechdel, Pekar, Sacco, and Delisle).

Graphic biography is also starting to receive wider attention, for example by academics such as Hilary Chute (2011) Tim Lanzendörfer (2014), Pramod K. Nayar (2016), Martha Kuhlman (2017), and Tierry Groensteen (2018). The bio/graphical genre has become increasingly popular since the late twentieth century, a phenomenon that Nayar relates to the memory boom that started in the 1990s (2016: 147). This scholar has explored the potential of auto/biographical comics to engage with issues of memory and trauma, as Marianne Hirsch's influential work (1993) on Maus had already revealed, and the ways in which they provide 'a new mode' to address social systems of oppression (Nayar 2016: 147). ${ }^{\text {i }}$ As argued by Nayar, 'national history and collective trauma in graphic auto/biography are often mediated through and embodied in personal anguish and individual stories of crises' (2016: 152), a statement that highlights the overlap between the historical and the auto/biographical genres, as well as the crucial links between personal and national histories.

Referring to textual biographies, Ruth Hoberman has suggested that 'biography is the terrain on which each generation works out crucial questions about its relation to the past' (1987: 204). One of the most crucial questions (perhaps the most crucial) of contemporary Spain has been that of how to deal with the memory of the Spanish Civil War and General Franco's dictatorship (1939-1975). This article will examine the conjuring power of memory to bring the ghosts of the traumatic past to the present in graphic biographies, taking as a case study the Galician comic Bóveda (2012) by María Xesús Arias (writer) and Carlos Sardiña (artist), about the life of the Galician politician Alexandre Bóveda (1903-1936), executed by 
Francoist forces on $17^{\text {th }}$ August 1936, a month after the military uprising against the Spanish Republican government and the beginning of the Civil War (1936-1939).

In order to provide the necessary historical context (essential for the full understanding of this comic), I will begin by outlining Bóveda's leading role as member of the Partido Galeguista [Galicianist Party] during the Spanish Second Republic (1931-1936), and the symbolical status he acquired after his assassination, as representative of democracy and Galician nationalism against Fascism. In doing so, the first section of the article will also engage with the politics or forgetting and remembering promoted in Spain since the end of Franco's dictatorship, and the debates around historical memory that have taken place in political and academic contexts. As a graphic biography, the comic will be also contextualised within the efforts to recuperate Bóveda's memory in the form of textual biographies and public homages since his assassination. My analysis of Bóveda therefore aims to position this comic within a network of publications and political events which have questioned the historiographical narrative created by the dictatorship in order to shed light on the repressed memories of those affected by the violence and the repression exerted by the regime. Since 2000 in particular (as I will explain in the first section of the article), the recuperation of the historical memory denied by Francoism has occupied a significant place in Spanish, and Galician, society and politics.

As the traumatic memories of the war "were made socially invisible for more than six decades and have therefore remained unarticulated and often suppressed' (Fernández de Mata 2010: 281), they have been described by scholars as having a 'ghostly' presence in Spanish culture, an allegory which has been also expressed in a number of films and novels about this period that revolve around the presence of ghosts (see for example Labanyi 2000 and Colmeiro 2011). Drawing on Jo Labanyi's influential use of Jacques Derrida's notion of 'hauntology' to examine Spanish contemporary history as a 'ghost story' (Labanyi 2000 \& 2002) and how these 'ghostly memories' challenge official history, the last section of this article will examine the narrative and visual potential of the graphic biography Bóveda to invoke a past that was repressed during the dictatorship, institutionally forgotten during the Transition and undermined by the conservative PP (Partido Popular - People's Party) Government at the time of its publication, in order to make it available for future generations.

My analysis will also draw on the term 'postmemory' coined by Marianne Hirsch (1993), to suggest that Bóveda's memory is transmitted through a process of creative mediation. In this regard, comics offer the possibility of bringing back not just the memory of the biographical subject (as textual biographies do) but also his/her body visually. The article 
will explore this question by looking at the specificities of the comics medium, compared to filmic representations of historical figures in biopics and documentaries, aiming to also contribute to the study of graphic biography in a wider sense.

\section{The Life and Death of Alexandre Bóveda: Historical Memory and the Ghosts of Galician History}

Galicia is today one of Spain's seventeen 'Autonomous Communities' and one of its 'historical nationalities' owing to having its own language, Galician, and a distinct cultural identity. However, the cultural and political development achieved by the incipient Galician nationalism at the beginning of the twentieth century was brutally stopped and repressed during the Spanish Civil War (1936-1939) and the ensuing dictatorship of General Franco (1939-1975). Although preceded by political movements such as Provincialismo [Provincialism] (1840-1885), Regionalismo [Regionalism] (1885-1915) and the cultural Rexurdimento [Renaissance] (1863-1880), which paved the way for a conceptualisation of Galicia as nation in the nineteenth century, scholars such as Bieto Alonso (1996: 262) and Uxío-Breogán Diéguez Cequiel (2015: 25) have established the origins of Galician nationalism in 1916 with the foundation of the Irmandades da Fala [Brotherhoods of the Language], whose main purpose was the defence and promotion of the Galician language.

Similarly to its Basque and Catalan counterparts, the Galician nationalist project aspired to achieve political and economic autonomy from the central government and the recognition of Galicia as a self-governing nation within an Iberian republican federation comprising the Basque Country, Catalonia, Galicia, Portugal and Spain (Granja, Beramendi and Anguera (2003: 108). With the arrival of the Spanish Second Republic in 1931, the Irmandades evolved into the Partido Galeguista (Galicianist Party), a democratic and republican organisation which sought the legitimation of their autonomist claims via an Estatuto de Autonomía [Statute of Autonomy, a law of devolution]. ${ }_{\text {ii }}$ From 1931 to 1936, the Galicianist Party focused its efforts in promoting the Statute amongst the Galician population (Granja, Beramendi and Anguera 2003: 161-164). In a referendum organised on $28^{\text {th }}$ June 1936, the Statute was overwhelmingly supported by Galician voters, but the rebel uprising a month afterwards hauled its implementation. .ii $^{\text {ii }}$

At the outbreak of the war, Galicia quickly fell to the rebel forces, a fact used by Francoist propaganda 'para alimentar o estereotipo dun pobo que eles afirmaban ser inherentemente dócil e mesmo agradecido pola intervención' [to fuel the stereotype [of 
Galicia] as a people that they argued was inherently docile and even grateful for the uprising], a fallacy that, as pointed out by John Thompson, 'segue a funcionar nos tempos actuais' [continues to work today] (2009: 20 for both quotes). The rebels systematically annihilated any political resistance against the uprising, as explicitly voiced by their leaders, for example by General Emilio Mola. ${ }^{\text {iv }}$ In Galicia, one of the effects of such organised and ruthless extermination, which Paul Preston has described as 'the Spanish Holocaust' (2012), was 'a decapitación da elite intelectual e política' [the decapitation of the political and intellectual elite], whose members were either killed or fled into exile (Alonso 1996: 271).

Alexandre Bóveda was a leading figure of the Partido Galeguista and one of the victims of the Fascist extermination. Accused of treason by the rebel forces, he was sentenced to death by a court martial and killed on $17^{\text {th }}$ August 1936. During the post-war years, Bóveda acquired a mythical status as a martyr of Galician nationalism, although he could not openly be remembered as such in Spanish territory. As José Colmeiro points out, 'memories of the civil war were officially repressed' and 'a unified Spanish national identity was imposed from above (one culture, one nation, one religion), as different identities from the periphery [...] were subjugated, cultural rights suppressed and censored by state apparatus' (2011: 24).

The memory of Bóveda's sacrifice and commitment to Galicia had to be kept alive by the Galician exiles, who in 1942 declared the day of his execution 'Día dos Mártires Galegos' [Day of Galician Martyrs] (Acuña 2003: 112), which could only be publicly celebrated in Galicia after the end of the Francoist dictatorship and from 1977. Bóveda became the symbol of 'Galicia Mártir' (those Galicians who had been killed by the Fascist forces), which was also the title of one of the three collections of drawings about the Civil War published by Alfonso Daniel Rodríguez Castelao, an artist, writer, and prominent figure of Galician nationalism. Castelao used one of the images from this collection as blueprint for his 1945 oil painting 'A derradeira leición do mestre' [The teacher's last lesson], which has been labelled the Galician Gernika. The work, painted in Buenos Aires as a tribute to Bóveda on the ninth anniversary of his execution, shows two children standing next to the lying body of a dead man, who bears a physical resemblance to the Galician politician. ${ }^{v}$ The exiles also published the biography Vida, paixón e morte de Alexandre Bóveda [Life, Passion and Death of Alexandre Bóveda] (1972) by Bóveda’s brother-in-law, Xerardo Álvarez Gallego.

After the dictator's death, the ensuing Transition into a democratic regime 'rested on a de facto "pact of silence" that avoided confrontation with those responsible for the dictatorship and denied public recognition of its victims' (Boyd 2008: 135). Institutionalised oblivion (using Joan Ramón Resina's words 2010: 227) contrasted with the growing interest 
in historical memory from the public, as evidenced by the amount of cultural products and historiographical publications dealing with the repressed past released in the mid-1980s. An example of the tension between memory and oblivion generated during the Transition is Xosé María Álvarez Bláquez’s biography Alexandro Bóveda (1992). Commissioned by the bank Banco del Noroeste in 1982, as part of their sponsored collection 'Hombres que hicieron Galicia' [Men who Made Galicia], the manuscript remained unpublished for ten years, arguably after the banks' realisation of Boveda's political significance. ${ }^{\mathrm{vi}}$

Following the world-wide 'memory boom', the late 1990s saw 'a flood of novels and collections of testimonies on the wartime and post-war repression as well as a significant number of fiction films and documentaries' (Labanyi 2007: 95). This production increased after 2000, when the horror of the war and the dictatorship was literally unearthed by the journalist Emilio Silva Barrera, founder of the Association for the Recuperation of Historical Memory (ARMH), who led the first exhumations of mass graves in Spain. As pointed out by Carolyn P. Boyd, 'images of mass graves and mutilated cadavers, fully exploited by the media, reached millions and clarified, for the first time for many Spaniards, the scope and brutality of the repression' (2008: 143), and also challenged the politics of forgetting, since they became 'a potent image and proof positive of what the Transition repressed' (Resina 2010: 234). Such visibility gave momentum to official initiatives for the recuperation of historical memory implemented by the government of the socialist party PSOE. 2006 was declared 'Year of Historical Memory' by the Spanish Parliament, and in 2007 it passed the Law of Historical Memory. ${ }^{\text {vii }}$

Institutional oblivion was also challenged by the Galician nationalist party Bloque Nacionalista Galego (BNG, Galician Nationalist Bloc), ${ }^{\text {vii }}$ which in the 1980s and 1990s paid tributes to Bóveda in the local governments where they had been elected, for example in the city of Pontevedra in 1999 (Bará 2012). Pontevedra's local council also funded the biography Alexandre Bóveda (1999) by Francisco Carballo. Coinciding with the 'memory boom' triggered by the exhumation of mass graves in 2000, the year 2003 was a turning point in recuperating Bóveda's memory. He was named 'favourite son' of the Ourense provincial council, and the Fundación Alexandre Bóveda organised a series of events to commemorate the centenary of his birth. 2003 also saw the release of two publications about his life: the biography Alexandre Bóveda. Motor do Galeguismo [Alexandre Bóveda. The Engine Driver of Galician Nationalism] (2003, funded by Ourense's provincial council) by Enrique Bande Rodríguez, and the photobiography Alexandre Bóveda. Na Historia do nacionalismo galego [Alexandre Bóveda. In the History of Galician Nationalism] (2003) by Xosé Enrique Acuña. 
After the passing of the 2007 Law of Historical Memory, institutional support for publications about the civil war increased, as shown by the illustrated biography Alexandre Bóveda. Unha vida por Galiza [A Life for Galicia] (2007) by Raimundo Martínez Fraga and drawn by Alberto Vázquez, jointly edited by the Asociación Cultural Alexandre Bóveda [Alexandre Bóveda Cultural Association] and the Xunta de Galicia. Similarly, the comic Compañeiros. Homenaxe ás vítimas do Portiño [Comrades. Homage to the victims of Portiño] (2008) by Xosé Tomás, published by the Comisión pola Recuperación da Memoria Histórica d'A Coruña [A Coruña Comission for the Recuperation of Historical Memory] received funding from the Spanish Government, the Xunta de Galicia, and A Coruña's provincial and local councils. Although it is not directly related to Bóveda's life, this comic challenges Galicia's often assumed peaceful rendition to and even support for the Fascist rebels, by remembering the killing and imprisonment of a group of members of the anarchosyndicalist CNT (National Labour Confederation, a trade union which had joined the resistance against the military uprising) while trying to escape from A Coruña by sea. ${ }^{\text {ix }}$

However, the victory of the conservative party PP in the 2011 Spanish general elections brought this institutional support to a halt. In 2012, the PP, which had been critical of the 2007 law and has refused to publicly condemn the Franco regime on several occasions (Boyd 2008: $143 \&$ 145), reduced the budget destined to the law by almost 60\%. A year later (also the year of publication of Bóveda), the PP Government left the Law of Historical Memory without any financial support, which meant an institutional involution to the 'desmemoria' [forgetting] of the Transition period (Palop 2017). ${ }^{\mathrm{x}}$

The graphic biography Bóveda (2012), inscribed in the process of raising awareness about the Galician politician's life and death, also reflects the lack of funding provided by the PP government to historical memory since 2011. Contrary to the biographies published after 2003, this comic did not receive any institutional support, but was instead fully financed thanks to a crowdfunding campaign. The summary of the project included in the Verkami website used to raise funds clearly connects this comic with previous initiatives by the exiles, contemporary biographers, the Alexandre Bóveda Foundation and the BNG: 'reivindicar e difundir a figura e o pensamento de Alexandre Bóveda, víctima dunha grave inxustiza. Condeado a morte e executado tras un irregular Consello de Guerra' [to recuperate and disseminate the role and ideas of Alexandre Bóveda, a victim of a serious injustice. He was sentenced to death and executed after an unlawful court martial].$^{\mathrm{xi}}$ In the following section, I will examine the narrative and visual mechanisms deployed in this comic in order to recuperate Bóveda's memory for a young readership. My analysis will also reflect on the 
potential of comics to return the biographee as a bodiless yet visible 'ghost'. By discussing the specific characteristics of this medium in contrast with filmic biopics, I aim to contribute to wider debates on the memorialising function of graphic biographies.

\section{Bóveda (2012): Invoking the Repressed Past in Graphic Biographies}

Bóveda does not follow the testimonial or academic style of previous textual biographies. It seems aimed mostly at children and having a didactic function. This is reflected in its narrative mode: Bóveda's life is told by an unnamed woman to her son after he has asked for help to write an essay for school. The comic's narrative is therefore structured upon the mother-son dialogue, during which the boy mostly asks questions and the mother adopts the role of a knowledgeable teacher. Her son's almost constant questioning suggests a lack of accessible information about Bóveda (and by extension about historical memory) for children and young adults, therefore highlighting the effects of institutionalised 'forgetting' politics promoted by the Transition and recuperated by the PP Government at the time of the release of the comic.

The invocation of Galicia's repressed history is visually represented by the existence of two chronological layers which either overlap or alternate: the present (the conversation between mother and son) and the past (Bóveda's life). The images of the past illustrate history as recounted by the mother. Rather than using a conventional mise-en-page divided in different panels, most of the comic makes use of splash pages, although sometimes there are two panels on the page, one representing the present and another one representing the past. Past and present are also joined by the use of a single narrative voice (the mother's), whose words appear at the bottom of some of the pages as a récitatif or voice-over.

These two temporal lines become increasingly close to each other as Bóveda's life progresses, a process reflected in the use of speech balloons. Whereas at the beginning of the comic these are restricted to the conversation between mother and son, they also become gradually integrated into the images that represent the past. Firstly, speech balloons appear as the mother's voice-over in one of the splash pages representing Bóveda's life (p. 15); the next page includes two panels (present and past), and the speech balloons from the mother-son dialogue also enter the space of the past represented in the adjoining panel (p. 16); a few pages later, a splash page representing the past includes two speech balloons containing the comments from both mother and son (p. 31), which also indicates an increasing involvement of the boy in the events of Bóveda's life. Finally, towards the end of the comic, the characters 
inhabiting the past, especially Bóveda, are also given a voice thanks to speech balloons (pp. $38,40,41,42 \& 43)$.

Luis Gasca and Roman Gubern explain the use of a voice-over through speech balloons as 'locuciones de personajes que no vemos, porque se hallan supuestamente ubicados fuera de la delimitación territorial señalizada por los bordes de la viñeta, o supuestamente ocultos al lector por algún objeto' [utterances made by characters that we cannot see, because they are supposedly located outside the territorial limits established by the gutter, or supposedly hidden to the reader by an object] (2001: 562). However, in this case, the presence of the 'voice-over balloon' does not respond to a spatial absence of the character in the panel, but rather to the coexistence of two temporal planes in the same image: the present in the words and the past in the image, thus reinforcing the links between both. Moreover, contrary to the examples provided by Gasca and Gubern and challenging conventional representations of speech in comics, it should also be noted that all speech balloons (both in the present and the past) have a discontinuous tail, resembling thought balloons, although from the visual context it is clear that they represent verbal utterances made by the characters (in both temporal planes). This could be explained as an unusual aesthetic choice, but since it blurs the distinction between saying and thinking, it also suggests a correspondence between saying and remembering, as if the past were invoked by the words of the characters.

[INSERT FIG. 1 HERE]

The biographical genre is characterised by its 'resurrecting' power. As Epstein notes, 'in the biographical narrative, language can convert life-made-text into text-made-life, can transform human death into biographical life and biographical death into a discursive existence continuously renewed' (1987: 27). The graphic-textual nature of comics also makes the return of the dead visible, by representing the body of the biographical subject. Following Hilary Chute, comics can 'map a life', which means that 'it is also about bodies - about locating them in space and time. [...] Embodiment in comics may be read as a kind of compensation for lost bodies, for lost histories. Comics resurrects and materializes' (2011: 122).

Graphic biographies are therefore similar to biopics in this regard: the spectator of a film can see a historical figure re-enacted in the body of an actor. However, the comparison with films in fact showcases the specificity of the comics medium. As Jean-Louis Comolli established, 'if the imaginary person, even in a historical fiction, has no other body than that of the actor playing him, the historical character, filmed, has at least two bodies, that of the 
imagery and that of the actor who represents him for us. There are at least two bodies in competition, one body too much' (1978: 44). On the contrary, in documentary films about a dead person there is 'a body too few' (Nichols 1997: 77). The representation of the body in graphic biographies does not entirely adhere to either of these two possibilities. Since in comics the body of the biographical subject is not 'brought back' through physical performance, it becomes simultaneously present and absent, as it inhabits the space of the panel, but lacks a 'real' physicality: it is a ghostly presence, a 'bodiless body'.

This ghostliness that characterises the body of the biographical subject in comics is especially productive when put into dialogue with the growing scholarship that deals with the 'haunted' nature of Spanish historical memory, as theorised by scholars such as Jo Labanyi (2000 \& 2002). Labanyi argues that the post-Franco era is 'a period haunted by a spectral Francoist past' (2001: 68). Drawing on Derrida's notion of 'hauntology' developed in Specters of Marx ([1993] 1994), she suggests that 'ghosts, as the traces of those who have not been allowed to leave a trace [...] are by definition the victims of history who return to demand reparation; that is, that their name, instead of being erased, be honoured' (2000: 66).

Following this assertion, the graphic biography invokes Bóveda's body in order to honour and rehabilitate his memory. However, his return from the dead can only be incomplete, as not only does he live in a 'bodiless body', but within the diegetic world Bóveda is also simultaneously dead (in the present plane) and alive (in the past plane). In her analysis of Maus, Chute places special emphasis on how Spiegelman's work 'represents history through the time and space of the comics page' (2009: 342). Although Maus follows a much more complex narrative, its basic principle is comparable to how Bóveda engages with the past: different temporalities are represented in separate panels that coexist on the same page and are therefore seen at the same time (in Bóveda this is also achieved by combining an image of the past with a voiceover that comes from the present); in Spiegelman's words: 'as a result you're always, in comics, being made aware of different times inhabiting the same space' (Spiegelman, quoted in Chute 2009: 342). This makes comics a medium especially suited to conveying the 'recalcitrant' and ghostly essence of memory, its recurrence and the reluctance to accept institutional oblivion: in contrast with the way in which, for History, the past is already behind, for memory it lives both then and now.

Galicia is also a particularly fruitful locus to explore the notion of history as ghostly, owing to how 'the phantasmal world of witches, ghosts and apparitions has played a central role in shaping Galicia's popular memory [...] but also in defining Galicia for the rest of Spain' (Barreto 2011: 386). Such tradition is at the centre of Castelao's famous speech 'Alba 
de gloria' [Dawn of Glory] delivered in Buenos Aires on 25th July 1945 as part of the celebrations of the Día de Galiza [Galicia's National Day]. In this speech, Castelao alludes to a series of key figures of Galician culture as belonging the Santa Compaña, a Galician rural legend according to which a procession of the dead wanders at night in search of new members. María do Cebreiro Rábade Villar, who has also examined the spectrality of Galician culture (2011), argues that 'Castelao invoca no seu discurso os espectros da nación, unha procession de desaparecidos que fai presente a quen escoita esa identidade galega dun xeito simultáneamente fuxidío e persistente' [in his speech, Castelao invokes the spectres of the nation, in a procession of the disappeared which makes Galician identity present in a simultaneously fleeting and persistent manner] (2011: 28). In Castelao's striking image of a nation of ghosts also transpires the repression of Galician culture in the mainland, and how, as a nation, Galicia could only exist (like a ghost) in exile. Rábade Villar suggests that 'ante todo, os espectros son formas de resistencia á desaparición, e esa resistencia manifestase na súa capacidade para se aparecer indefinidamente. Pero todos os que marcharon e regresan volven cunha tarefa' [above all, spectres are ways to resist against disappearance, and such resistance is manifested in their capacity to appear indefinitely. But all those who left and come back return with a task] (2011: 80). In the version of the speech published in his influential book Sempre en Galiza [Forever in Galicia] (1944), Castelao adds a reference to the Galician cemeteries, 'onde durmen os derradeiros mártires da Liberdade' [where the latest martyrs of freedom sleep], one of which is Bóveda, on whom Castelao bestows a postmortem quasi-messianic mission, as he 'terá que ser nun mañán próisimo ou lonxano a bandeira da nosa Redención' [will prove to be, in a near or distant tomorrow, the standard of our redemption] (2004: 526-527; for the translations Patterson 2016: 447). The task of Bóveda's ghost is to work as a reminder of both the brutality of Francoism and the emergence of the national consciousness obliterated by Fascism; his 'return' would also therefore mean the coming back of the national project he embodied from the ghostly and exiled condition to which it was condemned by the dictatorship.

Such a return is only possible through the invocation of memory. Fernández de Mata suggests that 'remembering - recordar, in Spanish [also in Galician] - implies returning through feeling, through the heart - cor in Latin'; remembering would then be 'related to reliving, for although it is impossible to repeat a past experience, the act of recordar evokes the sensations produced by that experience. To remember is to feel again' (2010: 281). In the case of Bóveda, however, the act of remembering/reliving is a mediated one. The account of the life of the Galician politician provided in the comic comes from other people's memories, 
especially those by Álvarez Gallego and Álvarez Blázquez as conveyed in their biographies. These two works, by people who knew him personally and witnessed his final days, also became a fundamental source for the subsequent biographies by Carballo and Bande Rodríguez. The comic seems in fact to follow the structure of Carballo's and even to reproduce some of its sentences almost verbatim. ${ }^{\text {xii }}$

However, the representation of the Galician politician in the graphic biography also presents differences when compared to its textual counterparts, which approach his figure from a hagiographical perspective. Álvarez Gallego refers to Bóveda's sacrifice twice; firstly, as he believed that by accepting his execution he would save some of his relatives from suffering the same fate (1972: 228), and secondly, as a sacrifice for the ideal of Galician nationalism (1972: 240). Carballo also states that Bóveda accepted his sentence "na esperanza de que a súa morte servira para procurar adeptos á causa que defendía' [in the hope that his death would help to gather support for his cause] (1999: 51). Álvarez Gallego, in fact, compares Bóveda to Christ, since the Galician politician was a religious person, also killed at 33 years of age as the result of an unjust trial. The hagiographical construction of the biographee has been pointed out by Michael Benton as a characteristic of literary biography, in which 'saintliness, idolatry and celebrity appear so frequently [...] that 'biomythography' is a more apposite term since it recognises the role of these aspects of myth-making' (2009: $48)$.

By contrast, these types of references are absent from the comic, which instead focuses on the unfounded accusations against Bóveda. In this case, the mythologisation of Bóveda as a martyr of the Galician nation exploits the visual specificities of the medium to create an emotional connection with the reader. The pages of the graphic biography that recount the court martial show medium close-ups of Bóveda: behind bars, escorted by the Civil Guard, defending his innocence at court, giving his last goodbyes to his wife and children, and writing his last wishes (pp. 36-46). The use of close-ups establishes a visual proximity with Bóveda, which allows for an affective identification between reader and biographee that goes beyond the political ideas he represented (alluded to in the speech balloons that include short extracts from his famous defence statement), and emphasises his personal and human tragedy. Such progressive identification with Bóveda at a personal level contributes to the gradual integration of the past into the present that I mentioned earlier.

The horizontal layout of the comic also adds to this emotional effect, as it is reminiscent of the shape of a photo album. The panels are, in fact, superimposed on a light brown background that imitates the worn off aspect of old photographs. Through this visual 
device, the memory of the nation is construed as personal memory. Similarly to the theorisation of the repressed memories of the Spanish Civil War as 'ghostly' by scholars such as Labanyi, Marianne Hirsch, in her study of postmemory and the Holocaust, also refers to the capacity of photographs to bring the past back:

[i]n its relation to loss and death, photography does not mediate the process of individual and collective memory but brings the past back in the form of a ghostly revenant, emphasizing, at the same time, its immutable and irreversible pastness and irretrievability. The encounter with the photograph is the encounter between two presents, one of which, already past, can be reanimated in the act of looking. (2001: 21)

Together with the publication of biographies since the late 1990s and the activities promoted by the Bóveda Foundation, this graphic biography is therefore part of a network of memorialising artefacts which re-imagine Bóveda's life and death as part of a shared collective memory, through a process of 'creative mediation', to borrow Hirsch's concept of 'postmemory': 'a powerful and very particular form of memory precisely because its connection to its object or source is mediated not through recollection but through an imaginative investment and creation' (2011:22). A case in point of such creative mediation is the re-enactment of Bóveda's execution, which is clearly inspired by Castelao's painting mentioned earlier. In the comic, although Bóveda's body is resting on the trunk of a tree instead of lying on the floor, the shape of this tree and its surroundings are similar to Castelao's image. His execution had also been previously re-imagined in the graphic biography Castelao (1987) by Siro, Mazaira and Cubeiro, where a panel representing Bóveda's assassination (here his body is lying on the floor in front of a bloody wall) is placed opposite to Castelao's drawing in the following page (on pp. 54-55), therefore enhancing a translinear and plurivectoral reading which also suggests the persistence of memory through the representation and repetition of trauma. ${ }^{\text {xii }}$

Compared to the feeling of absolute despair conveyed by previous representations, Bóveda's splash page adds an element of colour: a small green bird is on top of the tree, looking at the horizon as if looking at the future. It is a contrast between freedom and the repression that would ensue, but perhaps also a sign of the hope placed on the future generations, which will be inspired by Bóveda's sacrifice to continue the cause of Galician nationalism. A similar message is also suggested in the illustrated biography Alexandre 
Bóveda. Unha vida por Galiza (2007), which ends with the image of a tree growing from Bóveda's corpse. The last words included in this biography are in fact Castelao's famous sentence 'querían enterrar cadavres, pero enterraban semente' [they wanted to bury corpses, but they were burying seeds], which also reflects the symbolism given to Bóveda as martyr and beacon of Galician nationalism after his assassination.

\section{[INSERT FIG. 2 HERE]}

Postmemory, as defined by Hirsch, refers to "the relationship of children of survivors of cultural or collective trauma to the experiences of their parents' and the way in which the second generation remembers their memories, which they have only known as 'the narratives and images with which they grew up', as their own (2001: 9). However, in Bóveda such intergenerational transmission moves one generation up. The mother represents the grandchildren's generation (whose grandparents experienced the Spanish Civil War firsthand), the one that 'has predominantly come to ask the questions', since they 'have felt able to do so because, unlike many of their own parents' generation they feel safe - being sufficiently removed from the direct family trauma and the social and political context that generated it' (Graham 2005: 143). The grandchildren's questions are impelled by the silence that had been imposed on their parents and grandparents 'through the exercise of terror and power, as well as the complicit deafness of those who were not directly affected' (Fernández de Mata 2010: 285).

Their search for the repressed memories of Francoism (as exemplified by Emilio Silva and the ARMH) has also broken the institutional silence promoted by the Transition. Due to the regressive policies implemented around the time of the comic's publication, this narrative mode also suggests the grandchildren's responsibility to convey their acquired knowledge to their own progeny, the younger fourth generation embodied by the boy. Significantly, the comic does not seek to provide any closure, but rather to highlight the collective trauma represented by Bóveda's assassination. The graphic biography ends abruptly after the execution, with a final splash page in which the mother states: 'Quedaches sen palabras, Álex' [you're speechless, Álex]; and her son responding: 'É que isto si que é moi forte' [Because this is very shocking indeed]. The boy is unable to speak about the unspeakable trauma, which echoes 'the difficulty of articulating through language experiences of suffering, horror, and panic' for the victims of the Spanish Civil War, especially those who were children at the time (Fernández de Mata 2010: 282). The boy's empathy with the victims is confirmed by the identification between him and Bóveda, as they have the same name - Álex being a shorter version of Alexandre - and also share a physical resemblance, if 
we compare the last page with an earlier panel representing Bóveda as a child (p. 4). Alex's reaction to Bóveda's ghostly return exemplifies Hirsch's understanding of postmemory as 'a retrospective witnessing by adoption', that is, 'adopting the traumatic experiences - and thus also the memories - of others as experiences one might oneself have had, and of inscribing them into one's own life story', a process that she defines as 'an ethical relation to the oppressed or persecuted' (2001: 10).

As a device to invoke the past and transmit such 'ethical relation' to those who were killed and oppressed by Fascism in Spain (in this case, especially in Galicia), the graphic biography becomes a site of memory. Following Pierre Nora's concept (lieux de mémoire), Colmeiro has argued that 'monuments, museums, commemorations, symbols, books, documentaries, all can be considered collective "sites of memory", and the meanings taking shape in those sites have potential impact in the formation and consolidation of modern collective identities' (2011: 21-22). The same can be said of comics, perhaps even more so in the case of graphic biographies. When assessing the suitability of considering 'the biographical narrative as a monument to the biographical subject's memory', Epstein concludes that

the various intertwined senses of the terms 'monument' and 'memory' suggest how appropriate the image is to biography [...] the biographical narrative as monument/memory/memorial is a written document which records, identifies, enshrines, and entombs - a textualized token of fact which functions as the sacred, monumentalized structure of perpetuated memory. (1987: 28-29)

This also relates Bóveda's graphic biography (as well as the textual biographies) to the memorials erected after Franco's death to commemorate the victims of his regime. A bust of Bóveda in Pontevedra (where he lived from 1927 until his execution) was the first memorial of this nature inaugurated in Galicia, in 1986 (Thompson 2014-2015: 45). Tributes to Bóveda are held every $17^{\text {th }}$ August across Galicia, as part of the celebrations of the Día da Galiza Mártir. These events, especially the one taking place in front of his tomb in Santo Amaro's cemetery in Pontevedra, also work to invoke Bóveda's memory and keep it alive. From an institutional perspective, however, this remains a ghostly memory, as these celebrations do not have the support of the Xunta de Galicia. Moreover, despite the passing of the 2007 Law of Historical Memory, the invalidation of the judicial process against Bóveda has not been achieved to date (Bng.gal 2017). The institutional neglect generally suffered by Bóveda's 
memory (apart from the events organised by the nationalist party BNG) also showcases the resistance of some sectors of Spanish and Galician society to recognise the brutal consequences of the military uprising in 1936, both at a personal and at national level. Funded by individual donations, the graphic biography highlights the need to act outside the institutions in order to prevent Bóveda's ghostly memory from disappearing.

Thompson has, in fact, criticised the lack of public engagement achieved by the memorials of the civil war in Galicia, and argues that 'for a commemorative project to have a lasting effect, the public has to be involved and have a stake in it. [...] They lack strategies for engaging the rest of society and future generations' (2014-2015: 54). This scholar argues for the need to involve the young generations in creative activities that raise awareness about the Second Republic and the crimes of Francoism, so they become active participants in the process of remembering (2014-2015: 54-55), something that he has achieved with his project 'Pinta pasado, crea futuro' [Paint the Past, Create the Future] (Pardo 2016).

Although Bóveda is not the result of the type of collaborative art proposed by Thompson, it follows a similar premise. Because of the chosen narrative mode and the characters involved, the comic also emphasises the importance of keeping the younger generations aware of and engaged with the history of their own nation, often excluded from the grand narratives of the war. The comic's clear and informative approach to Bóveda's life and the central role played by the boy Álex, with whom a young audience can identify, also facilitates its use for teaching purposes and public activities that would involve the youth in the remembrance of the atrocities that took place in Galicia during the war and the dictatorship. Furthermore, comics (and graphic biographies in particular) are endowed with visual characteristics that make them especially suitable for bringing the past back, as they allow the ghostly return of the victims' bodies and inscribe them in a multiple, yet simultaneous chronological narrative that underscores the unfinished and recurrent nature of the personal and collective traumatic memory.

\section{Works Cited}

Acuña, Xosé Enrique (2003), Alexandre Bóveda. Na Historia do nacionalismo galego [Alexandre Bóveda. In the History of Galician Nationalism] Vigo: A Nosa Terra.

Alonso, Bieito (1996), 'Idade contemporánea (Século XX)', in Historia de Galicia [History of Galicia], ed. Francisco Carballo, Vigo: A Nosa Terra, pp. 235-280.

Álvarez Blázquez (1992), Xosé María, Alexandro Bóveda, Vigo: Ir Indo, 1992. 
Amigo Claudia, and Campos, Debora, 'Custodios ou propietarios: de quén é o patrimonio galego na diáspora' [Custodians or Propietors: Who Owns the Galician Heritage in the Diaspora?], in Luces 53, February 2018, pp. 76-81.

Arias, María Xesús and Sardiña, Carlos (2011), Bóveda, Narón: Son Radiodifusión.

Bande Rodríguez, Enrique (2003), Alexandre Bóveda. Motor do Galeguismo [Alexandre Bóveda. Engine of Galician Nationalism], Ourense: Duen de Bux.

Bará, Luis, 'Alexandre Bóveda e as institucións galegas' [Alexandre Bóveda and the Galician Institutions], Sermos Galiza [To Be Galiza] 17/08/2012 <https://www.sermosgaliza.gal/opinion/luis-bara/alexandre-boveda-e-as-institucionsgalegas/20120817031435004293.html> [accessed 4/06/2018].

Baquero, Juan Miguel, 'El Gobierno recupera con 15 millones la partida para Memoria Histórica en los Presupuestos" [The Goverment Recuperates the Funding of the Law of Historical Memory with 15 millons], El Diario 11/01/2019, < https://www.eldiario.es/sociedad/Gobierno-Espana-Memoria-Historicapresupuestos_0_856014972.html>[Accessed 16/03/2019].

Warf, Barney and Ferras, Carlos (2015), 'Nationalism, Identity and Landscape in Contemporary Galicia, Space and Polity, 19:3, pp. 256-272.

Barreto, Danny M. (2011), 'Ir de morto, ir de vivo: Galicians in a State of Living Death', Journal of Spanish Cultural Studies, 12:4, pp. 385-399.

Batens, Jan, 'Other Non-Fiction' (2017), in The Cambridge Companion to the Graphic Novel, ed. by Stephen E. Tabachnick, Cambridge: Cambridge University Press, pp. 130-143.

Benton, Michael (2009), Literary Biography. An Introduction, Malden; Oxford: WileyBlackwell.

Boyd, Carolyn P. (2008), 'The Politics of History and Memory in Democratic Spain', The Annals of the American Academy of Political and Social Science, 617, pp. 133-148.

Carballal, Ana (2017), 'Castelao: Nationalism, Federalism, and the Postcolonial', in Rerouting Galician Studies. Multidisciplinary Interventions, ed. by Benita Sampedro Vizcaya and José A. Losada Montero, Cham: Palgrave, pp. 179-189.

Carballo, Francisco (1999), Alexandre Bóveda, Vigo: A Nosa Terra, 1999.

Castells, Manuel (1997), The Power of Identity. Malden: Blackwell.

Chaney, Michael A. 'Introduction' (2011), in Graphic Subjects: Critical Essays on Autobiography and Graphic Novels, ed. by Michael A. Chaney, Madison: University of Wisconsin Press, pp. 3-9. 
Chute, Hillary (2009), 'History and Graphic Representation in Maus', in A Comics Studies Reader, ed. by Jeet Heer and Kent Worcester, University Press of Mississippi, 2009, pp. 340362.

(2011), 'Comics Form and Narrating Lives', Profession, pp. 107-117.

Comolli, Jean Louis (1978), 'Historical Fiction: A Body Too Much', trans. by B. Brewster, Screen, 19(2), pp. 41-53.

De la Granja Sainz José Luis and Justo G. Beramendi, La España de los nacionalismos y las autonomias (2001), [The Spain of Nationalisms and Autonomous Communities], Madrid: Síntesis.

Derrida, Jacques (1994), Specters of Marx. The State of the Debt, the Work of Mourning and the New International, trans. by Peggy Kamuf, New York \& London: Routledge.

Díeguez Cequiel, Uxío Breogán (2015), Nacionalismo galego aquén e alén mar [Galician Nationalism in Galicia and in Exile], Santiago de Compostela: Laiovento.

'El Congreso aprueba la reforma para anular los juicios políticos del franquismo' [The Spanish Parliament Approves the Reform to Annul the Political Trials of Francoism'], El Periódico [The Newspaper], 14/11/2017, https://www.elperiodico.com/es/politica/20171114/reforma-juicios-franquismo-6424128 [accessed 4/06/2018].

Epstein, William H. (1987), Recognizing Biography, Philadelphia: University of Pennsylvania Press.

(2011), 'Introduction: Biopics and American National. Identity. Invented Lives, Imagined Communities', in a/b: Auto/Biography Studies, 26:1, pp. 1-33.

Fernández de Mata, Ignacio 2010, 'The Rupture of the World and the Conflicts of Memory', in Unearthing Franco's Legacy. Mass Graves and the Recovery of Historical Memory in Spain, ed. by Carlos Jerez-Farrán and Samuel Amago, Notre Dame: University of Notre Dame Press, pp. 279-303.

Gasca, Luis and Gubern, Román (2001), El discurso del cómic [The discourse of comics] Madrid: Cátedra.

Antonio Gómez López-Quiñones (2010), 'Toward a Pragmatic Version of Memory. What Could the Spanish Civil War Mean to Contemporary Spain?', in Unearthing Franco's Legacy. Mass Graves and the Recovery of Historical Memory in Spain, ed. by Carlos JerezFarrán and Samuel Amago, Notre Dame: University of Notre Dame Press, pp. 208-220.

González-Millán, Xoan (2003), 'Exilio, literatura e nación' [Exile, literature and nation], Anuario Grial de Estudos Galegos [Grail Yearbook of Galician Studies], pp. 16-27. 
Graham, Helen (2005), The Spanish Civil War: s Very Short Introduction, Oxford \& New York: Oxford University Press.

Groensteen, Thierry (2018), 'Biographies of Famous Painters in Comics: What Becomes of the Paintings?', ImageTexT, 9:2, 2017, $<$ http://www.english.ufl.edu/imagetext/archives/v9_2/groensteen/> [accessed 26/05/2018]

Golob, Stephanie R. (2008), 'Volver: the Return of/to Transitional Justice Politics in Spain', Journal of Spanish Cultural Studies, 9:2, pp. 127-141.

Harrington, Thomas S., 2015, The Alchemy of Identity. Public Intellectuals and Nation Building in the Iberian Peninsula 1900-1925, Lanham: Bucknell University Press.

Hirsch, Marianne (1993), 'Family Pictures: Maus, Mourning, and Post-Memory', Discourse, 15: 2, pp. 3-29.

(2001), 'Surviving Images: Holocaust Photographs and the Work of Postmemory', The Yale Journal of Criticism, 14: 1, pp. 5-37.

(2012), Family Frames. Photography, Narrative and Postmemory, Cambridge; Massachusetts; London: Harvard University Press.

Hoberman, Ruth (1987), Modernizing Lives: Experiments in English Biography 1918-1939, Carbondale: Southern Illinois University.

Interview with Xosé Luís Bóveda Álvarez (no author) (2003), Murguía. Revista Galega de Historia [Murguía. Galician Journal of History] 2, online versión, <http://www.revistamurguia.com/aentrevistan2.htm> [accessed 4/06/2018]

Kuhlman, Martha, 'The Autobiographical and Biographical Novel' (2017), in The Cambridge Companion to the Graphic Novel, ed. by Stephen E. Tabachnick, Cambridge: Cambridge University Press, pp. 113-129.

Labanyi, Jo (2000), 'History and Hauntology; or What Does One Do with the Ghosts of the Past? Reflections on Spanish Film and Fiction of the Post-Franco Period', in Disremembering the Dictatorship: the Politics of Memory in the Spanish Transition to Democracy, ed. by Joan Ramón Resina, Amsterdam: Rodopi, pp. 65-82.

(2002), 'Engaging with Ghosts; or Theorizing Culture in Modern Spain', in Constructing Identity in Contemporary Spain, ed. by Jo Labanyi, Oxford \& New York: Oxford University Press, pp. 1-14.

(2007), 'Memory and Modernity in Democratic Spain: the Difficulty of Coming to Terms with the Spanish Civil War', Poetics Today 28:1, pp. 89-116.

(2010), 'Testimonies of Repression. Methodological and Political Issues', in Unearthing Franco's Legacy. Mass Graves and the Recovery of Historical Memory in Spain, ed. by 
Carlos Jerez-Farrán and Samuel Amago, Notre Dame: University of Notre Dame Press, pp. 192-205.

Lanzendörfer, Tim (2014), 'Biographiction: Narratological Aspects of Chester Brown's Louis Riel', Zeitschrift für Anglistik und Amerikanistik 59:1, pp. 27-40.

Martínez Fraga, Raimundo and Vázquez, Alberto (2017), Bóveda. Unha vida por Galiza [A Life for Galicia], A Coruña: Asociación Cultural Alexandre Bóveda.

Miranda-Barreiro, David (2018), 'From Pioneer of Comics to Cultural Myth: Castelao in Galician Graphic Biography', European Comic Art, 11:1, pp. 66-86.

Monteagudo, Henrique (2004), 'Alba de Gloria. A significación espiritual do día de Galicia: tecido dun texto' [Dawn of Glory. The Spiritual Significance of Galician's Day: the fabric of a text], in Dis(cursos) da escrita. Estudos de filoloxía galega ofrecidos en memoria de Fernando R. Tato Plaza [Dis(courses) of Writing. Studies of Galicia Philology, a Tribute to Fernando R. Tato Plaza], ed. by Rosario Álvarez and Antón Santamarina, A Coruña: Fundación Pedro Barrié de la Maza, pp. 553-575.

Nichols, Bill (1993), “'Getting to Know You...": Knowledge, Power, and the Body', in Theorizing Documentary, ed. by Michael Renov, New York: Routledge, pp. 174-191.

Nayar, Pramod K. (2016), 'Radical Graphics: Martin Luther King, Jr., B. R. Ambedkar, and Comics Auto/Biography', Biography, 39:2, pp. 147-171.

'O BNG ultima unha Lei de Memoria Histórica para anular os xuízos da Ditadura e devolver Meiras ao pobo' [BNG is Finalising a Law of Historical Memory to Annul the Trials of the Dictatorship and Return the Meirás House to the People], Bng.gal 18/8/2017 https://www.bng.gal/articulo/novas/bng-ultima-lei-memoria-historica-anular-xuizos-daditadura-devolver-meiras-ao-pobo/20170817184829020567.html [accessed 4/06/2018].

Pardo, Miguel, 'Arte en la calle para implicar a los más jóvenes en la memoria histórica' [Street Art to Get the Youth Engaged with Historical Memory], El Diario 16/08/2016, <https://www.eldiario.es/galicia/Arte-implicar-jovenes-memoriahistorica_0_548745426.html> [accessed 13/06/2018]

Patterson, Craig (2014a), "'Delito e pecado": Castelao, Galicia e o antisemitismo', Grial: revista galega de cultura, 202, pp. 52-63.

(2014b), 'From Racism to Redemption', Interventions: International Journal of Postcolonial Studies, 16:5, pp. 693-715.

Palop, María Eugenia R., 'La desmemoria histórica del Partido Popular: ni un euro para las víctimas del franquismo' [The historical forgetting of the PP: not even one euro for the victims of Francoism], El Diario [The Newspaper] 6/04/2017 <https://www.eldiario.es/zonacritica/desmemoria-historica-Partido-Popularfranquismo_6_630346988.html> [accessed 4/06/2017]. 
Preston, Paul (2010), 'Franco y la represión: la venganza del justiciero' [Franco and Repression: the Revenge of the Righteous], Novísima: II Congreso Internacional de Historia de Nuestro Tiempo [Newest: 2nd International Conference of Contemporary History], ed. by Carlos Navajas Zubeldía, Diego Iturriaga Barco, Logroño: Universidad de la Rioja, pp. 5970.

(2012), The Spanish Holocaust. Inquisition and Extermination in Twentieth-Century Spain, London: Harper Press.

Resina, Joan Ramon (2010), 'The Weight of Memory and the Lightness of Oblivion. The Dead of the Spanish Civil War', in Unearthing Franco's Legacy. Mass Graves and the Recovery of Historical Memory in Spain, ed. by Carlos Jerez-Farrán and Samuel Amago, Notre Dame: University of Notre Dame Press, pp. 221-242.

Rodríguez Castelao, Alfonso Daniel (2004), Sempre en Galiza [Forever in Galicia], in Obras [Complete Works], volume 2, $2^{\text {nd }}$ edition, ed. by H. Monteagudo, Vigo: Galaxia.

_ (2016), Forever in Galicia, trans. by Craig Patterson, London: Francis Boutle Publishing. Santidrián Arias, Víctor Manuel (2007), 'Las cosas de la memoria (histórica)' [The Things of the Historical Memory], Hispania Nova 7, pp. 401-412.

Tomás, Xosé (2008), Compañeiros. Homenaxe ás vítimas do Portiño [Comrades. Homage to the victims of Portiño], A Coruña: Comisión pola Recuperación da Memoria Histórica d'A Coruña.

Thompson, John (2009), As novelas da memoria. Trauma e representación da historia na Galiza contemporánea [The Novels of Memory: Trauma and the Representation of History in Contemporary Galicia], Vigo: Galaxia.

(2014-2015), 'Galician Memorials: Civic Activism and Shortcomings', Galicia 21. Journal of Contemporary Galician Studies, Issue F, pp. 43-59. 
i Nayar's analysis of Ho Che Anderson's King (2010) about Dr. Martin Luther King, and S. Anand and
Srividya Natarajan's Bhimayana (2011) focuses on 'racism and caste-based oppression' (2016: 147).
ii Compared to initial 19 $9^{\text {th }}$ century cultural formulations of Galician nationalism, heavily inspired by Romanticism and imbued with quite problematic claims about the racial purity of the Celtic peoples (considering Galicia a having a Celtic heritage) (see for example Harrington 2015: 146-147), the form of Galician nationalism represented by the Partido Galeguista led by Alfonso Daniel Rodríguez Castelao and Alexandre Bóveda was a political project, democratic, federalist, republican, anti-imperialist and anti-racist. Although Castelao held racist views towards some ethnic groups (see Patterson 2014a and 2014b), he also disregarded racial or ethnic purity as a condition for nationhood. In his seminal work Sempre in Galiza [Forever in Galicia] (1944), he argued that '[f]or us, the Galicians, accustomed to roaming the world and coexisting with all races, racist nationalism is a crime and also a sin. We never measure the diameters of our skull, nor do we measure those of anybody else for them to be accepted into our community' (2016: 49). According to Ana Carballal, 'Castelao linked the building of a nation with concrete political objectives [...]. There was an urgency to create a new form of coexistence that would embrace universality, justice, preservation of the environment and, above all, the tradition and history contained in the language' (2017: 183).

iii The Estatuto was approved in 1945, although this was undertaken by the Spanish Republican Government in exile in Mexico and therefore had no legal effect within Franco's regime. The Spanish Republican government had passed the Statute of Autonomy of Catalonia in 1932. The Statute of Autonomy for the Basque Country was passed in 1936, during the Civil War. These laws of devolution were the precedent for the Statutes passed in the democratic period, which are currently in place.

iv 'hay que sembrar el terror [...] Hay que dar sensación de dominio eliminando sin escrúpulos ni sin vacilación a todos los que no piensen como nosotros' [we must spread terror [...] We must give an image of full control, eliminating without scruple or hesitation all of those who do not think as we do' (quoted in Preston 2010: 59).

${ }^{\mathrm{v}}$ See for example Claudia Amigo and Debora Campos (2018).

${ }^{\text {vi }}$ This is explained in the prologue to the biography by Alfonso Álvarez Cáccamo.

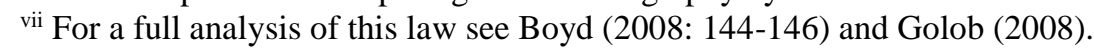

viii Barney Warf \& Carlos Ferras define BNG as follows: "[f]ounded as a "patriotic front" in 1982, the BNG is a political coalition composed of several parties and currents of thought, including the Unión do Povo Galego (Union of the Gallegan People), the Movemento Pola Base (the Grassroots Movement) and Partido Galeguista (Gallegan Party). It thus embraces various leftist, socialist, communist and nationalist factions' (2015: 263).

ix Although the present article focuses on Galician comics, it is worth noting that a significant number of Spanish comics have also dealt with the repressed memory of the Civil War and the dictatorship; for example Antonio Altarriba's El arte de volar [The Art of Flying] (2009), Paco Roca's Los surcos del azar [The Tracks of Fate] (2013), Carlos Guijarro's El paseo de los canadienses [The Canadians Promenade] (2015), and the graphic biography Vida y muerte de Federico García [Life and Death of Federico García Lorca] (2018) by Ian Gibson and Quique Palomo, to name a few.

${ }^{x}$ At the time this article is being written, the PP was ousted from the Spanish government after a vote of no confidence. The new Prime Minister, Pedro Sánchez from PSOE, reactivated some aspects of the Law of Historical Memory (see Baquero 2019). New General Elections will be held on $28^{\text {th }}$ April 2019, and the continuity of this law will depend on the results.

${ }^{x i}$ See https://www.verkami.com/projects/3643-boveda-un-alegato-pacifista-contra-a-inxustiza

xii Compare for example Carballo's biography, p. 39: 'Houbo unha utilización novidosa da radiodifusión, de vehículos con autoparlante e mesmo do cinema' [There was an innovative use of radio broadcasting, of vehicles with speakers and even of cinema], with the comic, pp. 28-29: 'Foi unha campaña moi novidosa, nunca vista en Galiza. A radio xogou un papel fundamental e tamén o cinema. Os coches con altofalantes chamaban a atención da xente nas ciudades, vilas e rueiros' [It was a very innovative campaing, never seen in Galiza. Both the radio and cinema played a key role. Cars with speakers called the attention of people in cities, towns and squares]. xiii For an analysis of graphic biographies of Castelao, see Miranda-Barreiro (2018). 